\title{
Pengaruh Pemberian Susu Afkir terhadap Konsumsi Pakan, Pertambahan Bobot Badan Harian dan Konversi Pakan Broiler
}

\section{The Effect of Rejected Dairy Milk on Feed Intake, Daily Weight Gain and Feed Conversion Ratio of Broiler}

\author{
Muhammad Angsori ${ }^{1}$, Wati $\mathrm{NE}^{1}$, Wicaksana $\mathrm{K}^{1}$ \\ Fakultas Peternakan, Universitas Tulang Bawang Lampung, Jl. Gajah Mada, Bandar \\ Lampung \\ Angsori090190@gmail.com
}

\begin{abstract}
The objective of this experiment was to determine the effect of rejecting milk on drinking water on feed intake, daily body weight gain and feed conversion of broilers. The material of this study included 200 broilers aged 14 days given $\mathrm{P} 0=$ drinking water treatment without giving an reject milk and $\mathrm{P} 1=$ drinking water with the addition of rejected milk. Chickens were treated for 14 days and fed with $\mathrm{PK}=22.0-23.0 \%$, Fat $=5.0 \%$, Calcium $=$ $0.9 \%$, Phospor $=0.6 \%, \mathrm{ME}=3050-3150 \mathrm{Kcal} / \mathrm{Kg}$. In conclusion, rejected milk in drinking water has a significant effect on daily body weight gain, but does not significantly effect on feed intake and feed conversion. The daily body weight gain of P1 was higher than P0.
\end{abstract}

Keywords: broilers, daily weight gain, feed intake, feed conversion ratio, rejected dairy milk

\section{PENDAHULUAN}

Keberhasilan usaha beternak ayam ras pedaging ditentukan oleh empat faktor dasar yang sangat berperan penting antara lain adalah pemilihan bibit unggul, kualitas dan kuantitas pakan, tata laksana pemeliharaan, serta pengendalian penyakit. Pakan merupakan faktor produksi yang membutuhkan biaya tinggi dalam usaha ternak ayam ras pedaging yaitu $65 \%-75 \%$ dari seluruh biaya produksi (Santoso, 1999). Selain itu permasalahan yang sering dialami peternak ayam ras pedaging adalah harga pakan yang semakin tinggi tetapi kualitas semakin menurun. Dengan kondisi demikian peternak harus mampu mensiasati agar input faktor produksi yang digunakan memiliki harga yang terjangkau, mudah didapat, dan memiliki kualitas baik.

Pemanfaatan susu afkir merupakan salah satu alternatif untuk menekan biaya pakan pada ternak dengan cara ditambahkan pada pakan ayam ras pedaging. Diharapkan dengan pemberian susu afkir bisa meningkatkan asupan nutrisi sehingga dapat mempercepat masa panen sehingga biaya untuk pakan ayam pedaging lebih rendah. Penambahan susu afkir diharapkan dapat memperbaiki kualitas ransum dan meningkatkan proses pencernaan penyerapan zat nutrisi ransum (Katsir, 2003). Tujuan penelitian ini adalah untuk mengetahui pengaruh pemberian susu afkir terhadap konsumsi pakan, pertambahan bobot badan harian dan konversi pakan pada ayam ras pedaging. 


\section{METODOLOGI PENELITIAN}

Penelitian ini dilaksanakan pada Februari 2018 di Farm Lebung Sari, Kecamatan Merbau Mataram, Kabupaten Lampung Selatan.

Materi yang digunakan dalam penelitian ini yaitu 200 ekor ayam, 100 ekor untuk P0 dan 100 untuk P1. Alat yang akan digunakan dalam penelitian ini meliputi: kandang indukan, kandang baterai, tempat makan, tempat minum, lampu pijar 60 watt, timbangan analitik dan karung. Kandang indukan terbuat dari kayu dengan lantai dilapisi kertas koran dan dilengkapi dengan tempat makan dan minum yang terbuat dari plastik serta dilengkapi pula dengan empat buah lampu pijar berkekuatan 60 watt sebagai pemanas. Sekeliling kandang dilapisi dengan karung agar ayam tetap hangat dan mencegah suhu dingin yang masuk. Kandang baterai sebagai kandang perlakuan dibuat dari kayu dan dibagi atas beberapa petak. Kandang baterai ini juga dilengkapi oleh tempat pakan dan minum serta tempat penampung kotoran. Timbangan analitik digunakan untuk menimbang susu afkir dan pakan komersial. Bahan yang digunakan meliputi ayam ras pedaging sebanyak 200 ekor, Biocid dan susu afkir, pakan yang digunakan adalah pakan dari Caroen Pokphand H-11. Konsumsi nutrien pakan ayam tertera pada Tabel 1.

Tabel 1. Kandungan Nutrien Pakan

\begin{tabular}{ll}
\hline Nutrien & Kandungan Nutrien \\
\hline Kadar Air & $13,0 \%$ \\
Protein & $22,0-23,0 \%$ \\
Lemak & $5,0 \%$ \\
Serat & $5,0 \%$ \\
Abu & $7,0 \%$ \\
Calsium & $0,9 \%$ \\
Phosphor & $0,6 \%$ \\
ME & $3050-3150 \mathrm{Kcal} / \mathrm{kg}$ \\
\hline
\end{tabular}

Sumber: Pakan Charoen Pokphand $\mathrm{H}-11$

Persiapan kandang dilakukan dua minggu sebelum pemeliharaan ayam ras pedaging dimulai. Kandang baterai dibersihkan dan didesinfektan terlebih dahulu menggunakan Biocid, sedangkan lokasi kandang dibersihkan dan difumigasi mengunakan campuran antra $\mathrm{KMnO} 4$ dan formalin. Lampu dinyalakan terlebih dahulu sebelum ayam ras pedaging dimasukkan agar suhu di dalam kandang menjadi hangat.

Pada minggu kedua (umur 14 hari) sampel ayam ras pedaging dari kandang indukkan dipindahkan ke kandang perlakuan yaitu kandang baterai yang dibedakan menjadi dua kelompok yang masing-masing terdiri dari sepuluh ulangan. Kedua kelompok tersebut mulai diberikan pakan perlakuan yang berbeda yaitu P0 dan P1 secara ad libitum. Perlakuan P0 : air minum tanpa penambahan susu afkir (kontrol) dan P1 : air minum + susu afkir. Susu afkir diberikan sebanyak $5 \mathrm{~g}$ susu dalam 1 It air pada air minum ayam ras pedaging yang berumur 14 sampai dengan 28 hari. Susu afkir yang diberikan adalah merk SGM Ananda. Penyediaan dan pemberian air minum pada farm Lebung Sari dilakukan secara ad libitum terukur, didukung dengan gallon otomatis sehingga ayam dapat mengkonsumsi air minum secara bebas dan ketersediaan air minum menjadi tetap pada setiap gallon. 
Selain pemberian air minum yang dilakukan dengan ad libitum, pengawasan kondisi gallon dan ketersediaan air minum harus tetap diperhatikan.

Sebelum diberikan pakan perlakuan semua ayam ditimbang untuk mengetahui berat badan awal. Setiap minggu dilakukan penimbangan berat badan (pada umur 14 hari, 21 hari, dan 28 hari). Setelah itu mengumpulkan sisa pakan yang ada pada petak kandang, lalu ditimbang untuk mengetahui konsumsi pakan tiap ayam. Hal ini berlangsung hingga masa panen yaitu pada akhir minggu kelima. Total waktu perlakuan selama 21 hari.

Pengukuran bobot DOC pada Farm Lebung Sari dengan cara dilakukan penimbangan. Pengambilan data untuk pertambahan bobot badan dilakukan pada awal masa perlakuan dan hari terakhir perlakuan. Pertambahan bobot badan diukur dengan menimbang berat badan pada masa awal perlakuan dan bobot akhir masa perlakuan. Pertambahan bobot badan dihitung dari nilai konversi pakan dengan cara menghitung jumlah total pakan yang dikonsumsi selama tiga minggu perlakuan dibagi dengan pertambahan bobot badan dalam kurun waktu yang sama.

\section{HASIL PENELITIAN}

\section{Pengaruh Perlakuan terhadap Konsumsi Pakan}

Rata-rata konsumsi pakan ayam yang mendapat perlakuan P0 dan P1 tersaji pada llustrasi 1.

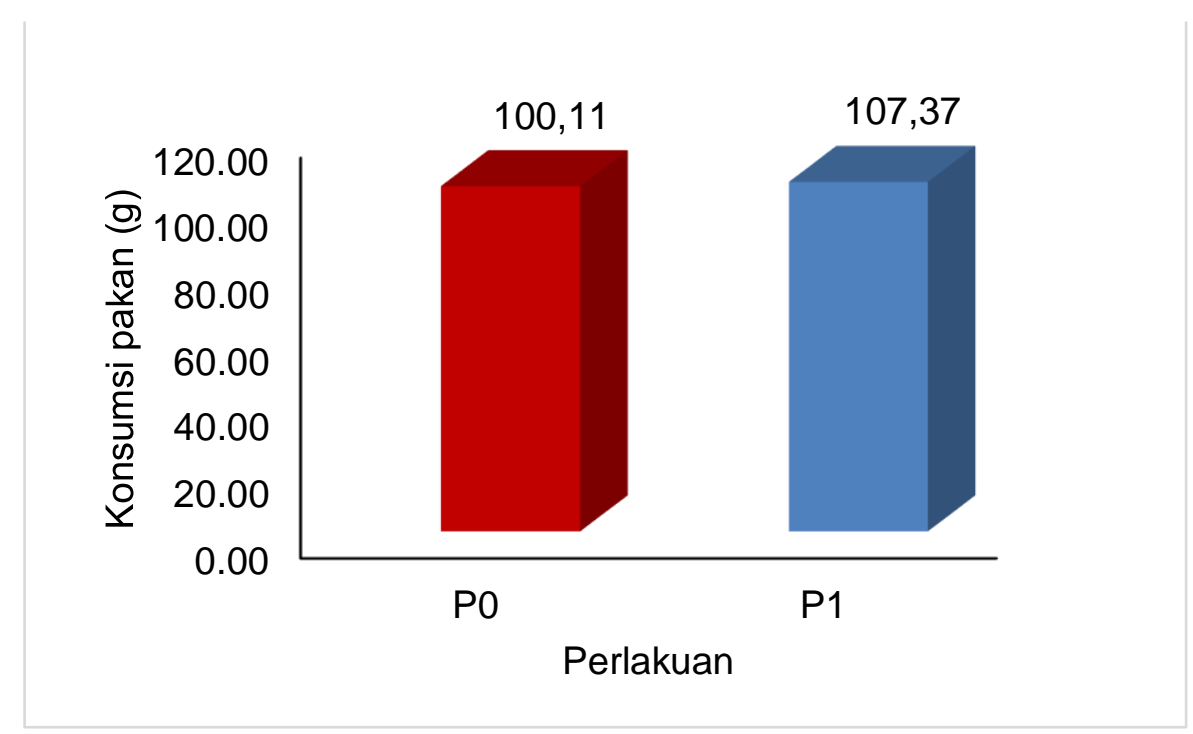

Ilustrasi 1. Rata-rata konsumsi pakan ayam P0 dan P1

Besarnya konsumsi pakan ayam yang mendapat perlakuan P0 dan P1 tidak berbeda nyata $(P>0,05)$ yaitu sebesar $100,11 \mathrm{~g}$ dan $107,37 \mathrm{~g}$. Hal ini kemungkinan disebabkan karena susu afkir ditambahkan didalam air minum sehingga tidak berpengaruh terhadap konsumsi pakan. Hal ini sesuai dengan pendapat Habibi et al. (2017) bahwa penambahan susu afkir pada pakan ayam petelur 6-14 minggu tidak berpengaruh nyata terhadap konsumsi pakan. 


\section{Pengaruh Perlakuan terhadap PBBH}

Hasil penelitian pemberian susu afkir dalam pakan ayam ras pedaging terhadap pertambahan berat badan pada ayam ras pedaging umur 14-28 hari menunjukan perbedaan yang nyata $(P<0,05)$ antar perlakuan, berikut data pertambahan bobot badan harian ayam yang diberi perlakuan $\mathrm{P} 0$ dan $\mathrm{P} 1$ tersaji pada Tabel 2.

Tabel 2. Data pertambahan bobot badan harian dengan perlakuan P0 dan P1

\begin{tabular}{cccc}
\hline Nomor & Perlakuan & PBBH $(\mathbf{g})$ & Standar Deviasi \\
\hline 1 & P0 & 72,75 & 10,02 \\
2 & P1 & 77,81 & 13,20
\end{tabular}

Sumber : Data Primer Penelitian, 2018.

Pertambahan bobot badan harian dengan perlakuan P0 dan P1 tersaji pada llustrasi 2

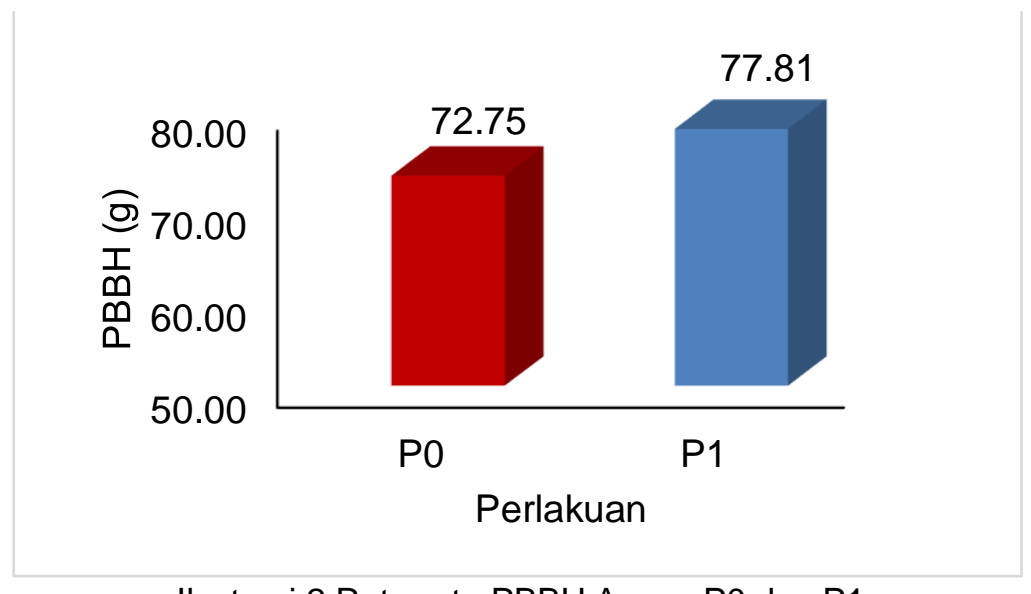

Ilustrasi 2 Rata-rata PBBH Ayam P0 dan P1

Besarnya pertambahan bobot badan harian P1 lebih besar dari pada P0, hal ini disebabkan karena jumlah nutrien yang masuk ke dalam tubuh ayam P1 lebih tinggi dari pada ayam P0. Nutrien tersebut berasal dari susu afkir yang ditambah pada air minum ayam P1.

Kandungan nutrien yang meliputi protein, karbohidrat, lemak, serat kasar, kalsium, bahan kering, Bahan Ekstrak Tanpa Nitrogen (BETN) serta energi metabolisme yang berbeda dapat berpengaruh pada pertambahan bobot badan harian. Protein merupakan zat nutrisi utama yang berguna untuk pertumbuhan dan pembentukkan sel-sel baru pada organ-organ tubuh. Semakin tinggi kandungan protein yang dikonsumsi, pertumbuhan yang terjadi juga semakin besar dan sebaliknya jika protein yang dikonsumsi kurang maka pertumbuhan akan terhambat (Nasution, 2009). Faktor lain yang mempengaruhi kecepatan pertumbuhan ayam pedaging adalah tipe ayam, jenis kelamin, pakan yang diberikan, tata laksana dan temperatur lingkungan (Rasyaf, 2001). 


\section{Pengaruh Perlakuan terhadap Konversi Pakan}

Hasil penelitian mengenai pengaruh pemberian susu afkir terhadap konversi pakan pada ayam ras pedaging menunjukkan perbedaan yang tidak nyata $(P>0,05)$ antar perlakuan. Data besarnya konversi pakan pada ayam ras pedaging umur 14-28 hari selengkapnya disajikan pada Tabel 3.

Tabel 3. Konversi Pakan

\begin{tabular}{ccc}
\hline Nomor & Perlakuan & FCR \\
\hline 1 & P0 & 1,45 \\
2 & P1 & 1,40 \\
\hline
\end{tabular}

Sumber: Data Primer Penelitian, 2018

Rataan konversi pakan ayam yang mendapat perlakuan $\mathrm{P} 0$ dan $\mathrm{P} 1$ tersaji pada ilustrasi 3.

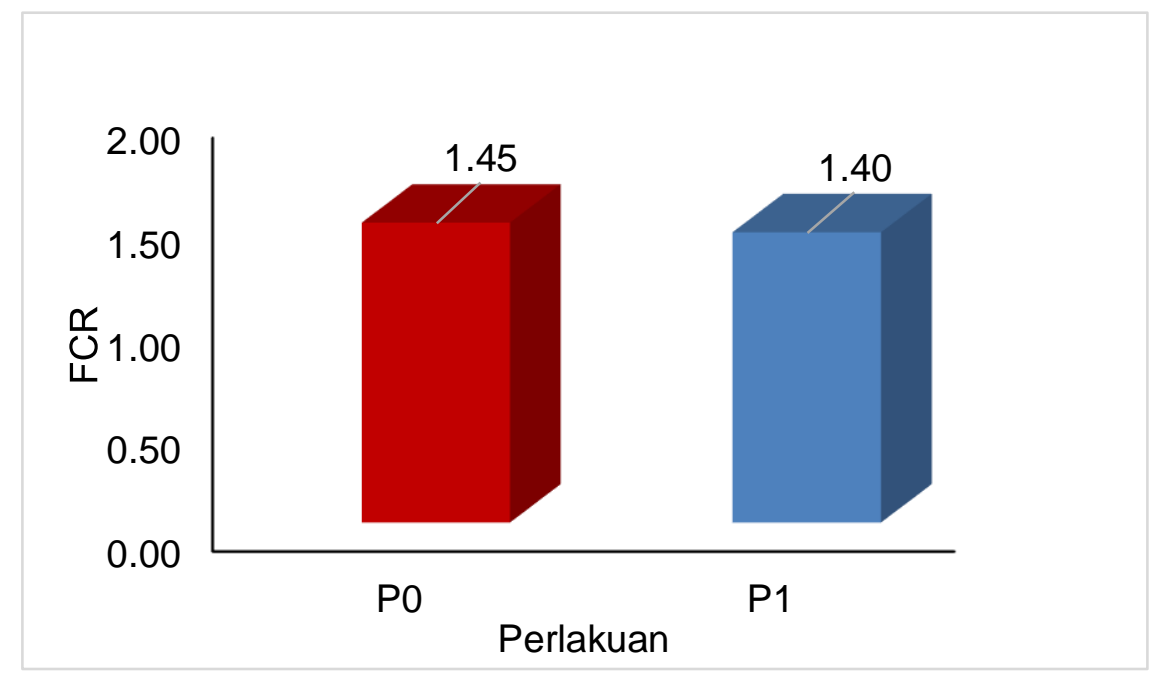

Ilustrasi 3. Konversi Pakan pada Ayam P0 dan P1

Besarnya konversi pakan ayam P0 tidak berbeda nyata dengan P1. Hal ini disebabkan karena jumlah konversi pakan yang tidak berbeda meskipun pertambahan bobot badan harian ayam P1 lebih besar daripada P0. Hal ini sejalan dengan hasil penelitian Habibi et al. (2017) bahwa penambahan susu afkir sebesar $0 \%, 2,5 \%, 5 \%, 7,5 \%$ pada pakan ayam petelur umur 6-14 minggu tidak berpengaruh nyata terhadap konversi pakan. Anggorodi (1994), menambahkan bahwa besar kecilnya konversi pakan dipengaruhi oleh daya cerna ternak, kualitas pakan yang dikonsumsi, serta keserasian nilai nutrien yang dikandung pakan tersebut. Semakin kecil konversi pakan maka akan semakin menguntungkan karena semakin sedikit jumlah konsumsi untuk menghasilkan daging selama waktu penelitian (Nasution, 2009). 


\section{KESIMPULAN}

Pemberian susu afkir pada air minum berpengaruh nyata terhadap pertambahan bobot badan harian, tetapi tidak berpengaruh nyata terhadap konsumsi pakan dan konversi pakan. Pertambahan bobot badan harian ayam yang diberi susu afkir lebih tinggi dari pada ayam yang tidak diberi susu afkir.

\section{DAFTAR PUSTAKA}

Anggorodi, R. 1994, Ilmu Makanan Ternak Umum. Jakarta: PT Gramedia, Habibi, Habibi and Warnoto, Warnoto and Setianto, Johan. 2017 Pengaruh Pemberian Susu Bubuk Afkir Terhadap Performans Pertumbuhan Ayampetelur Umur 6 - 14 Minggu. Undergraduated thesis, Universitas Bengkulu

Katsir, I. 2003. Pentingnya Suplementasi Ransum. Info Medion. Bandung

Nasution. 2009. Metode Research: Penelitian Ilmiah. Jakarta: PT. Bumi Aksara.

Rasyaf, M. 2001. Beternak Ayam Pedaging. Cetakan Ke-XX. Jakarta: Penebar Swadaya.

Santoso. 1999. Pembibitan Ayam Ras. Jakarta: Penebar Swadaya. 